\title{
F-Word or Blueprint for Institutional Reform? European Integration and the Continued Relevance of Federalism
}

\author{
Maximilian Conrad, Ph.D., Assistant Professor, Freyja Steingrímsdóttir, B.A.
}

\begin{abstract}
Federalist thought has historically been an important source of inspiration in European integration. Although the last few decades have witnessed a gradual decline of the concept's relevance, the most recent developments in the wake of the Eurozone debt crisis have drawn renewed attention to shortcomings in the European Union's institutional architecture as well as to the feasibility of federal solutions to such institutional shortcomings. This article explores the potential of federalist thought as a blueprint for institutional reform in the EU. Based on a brief introduction to the concept of federalism, the article contextualizes federalism in debates on the democratic deficit, the EU's sources of legitimacy and the relationship between the union institutions and the member states. If shortcomings in institutional design are the source of the current (and future) crises, then closer attention needs to be paid to the costs and benefits of federal reorganization in terms of democracy, legitimacy and sovereignty, particularly from the perspective of small states in the EU. Federal reorganization would not only improve the democratic character of EU decision making, but also strengthen the role of small states in the union. However, it also prompts a number of thorny questions, most importantly regarding the construction of a European demos and its relationship to deeply engrained ideas about the nation state as a more or less natural home of democracy.
\end{abstract}

Keywords: European Union, federalism, institutional reform, democratic deficit, postnational democracy, constitutional patriotism.

\section{Federalism: Still Relevant in European Integration?}

Federalist thought has historically been an important source of inspiration for European integration, both as a vision and as a concrete process of institution building. Many of the key thinkers advocating European unification in the interwar period as well as during and after World War II were declared federalists, the most prominent examples of whom include figures such as Coudenhove-Kalergi or Spinelli and Rossi. Even the Monnet method of incremental integration, to be distinguished from the revolutionary federalism of the Ventotene Manifesto, is based on a clear 
normative preference for a gradual federalization of Europe. But also more recent proponents of European federalism such as Joschka Fischer and Guy Verhofstadt are testimony to the lasting legacy of federalism in thought about the European integration process, as is Spinelli's work in the European Parliament for much of the rest of his life.

Recent decades have however witnessed a gradual decline of the relevance of federalist ideas as a driving force for leading European politicians. While Fischer and Verhofstadt are still quite frequent in their pleas for a strengthening of the supranational European institutions and a decisive move in the federal direction, it has correctly been pointed out that most leading politicians nowadays tend to shy away from using what has increasingly come to be perceived as the F-word in European integration, even when promoting a significant strengthening of the European institutions. Nonetheless, the Eurozone debt crisis and the institutional reform responses which it has prompted - not least from federalists - urge a reconsideration of the costs and benefits of federal reorganization in terms of the sovereignty of the nation state, the alleged democratic deficit in the European Union, and the strategies for legitimation available to the EU. The purpose of this article is to explore these issues in order to provide a conceptual basis for further discussion on federal reorganization in the EU, specifically in the context of Icelandic public debate on the EU and Iceland's role as a potential future member state. What would or could a European Union organized according to federal principles look like, and what would the role and power potential of small states be in a polity of this kind? There is certainly an element of speculation in asking this question, as there is evidently not one single way of organizing a federal polity. Nonetheless, federalist theory not only continues to be of particular relevance to organizations building central institutions on the basis of already existing constituent units, but also gives us enough theoretical guidance to stake out a variety of institutional options for a federal European polity.

Based on a brief conceptual introduction to federalism, we contextualize federalism in debates on the future of the EU as a polity and on the sources of the union's legitimacy. We then proceed to an illustration of the legacy of federalist thought in the history of European integration, before we address concrete institutional reforms along federal lines that have been debated in recent years. Most importantly, we also address the question of the role of small states in an EU reorganized along federal lines.

\section{Sources of Legitimacy in European Integration}

Legitimation continues to be a contested issue in European integration. A democratic deficit in the EU has come to be regarded as a fact, although it is by no means selfevident what constitutes this democratic deficit, on what conceptual basis such assessments are made, and arguably least of all what institutional solutions are available (Conrad 2010). While most scholars acknowledge the existence of some form of democratic deficit, Giandomenico Majone and Andrew Moravcsik contest this conventional wisdom. Moravscik goes so far as to argue that democratic legitimacy is 
an inappropriate concept for assessing the EU's performance, basing his argument on the assertion that the European integration process is situated squarely within the realm of international relations: as an intergovernmental organization, the EU should not be subjected to the same expectations on democratic performance as a constitutional state. In addition, the most important legislative institutions - the Council of Ministers and the European Parliament - are directly elected and/or directly accountable to electorates within the member states (Moravcsik 2008). Majone takes a similar stance, maintaining that the EU's legitimacy rests on the legitimacy of national, democratically accountable governments, since the entire process is guided and controlled by sovereign member states (Majone 1998: 12).

Yet the European Union is clearly more than an intergovernmental organization (Eriksen \& Fossum 2004, 2007). There is some truth to the conventional wisdom that the European Union is "polity sui generis", which is underlined by the complex mix of supranational and intergovernmental elements in the EU's institutional architecture. This leads to the question as to how much (and indeed what kind of) democracy is necessary and possible at the European level, but also what sources of legitimacy the integration process can draw on. From a federalist perspective, one evident root cause of the democratic deficit is institutional design. Most of the democratic shortcomings that are usually emphasized by Euroskeptics could be fixed in a process of federal reorganization. Such issues prominently include the lack of accountability of the European Commission, the (still) quite limited role of the European Parliament, the independent role of the European Court of Justice, and so on. Such deficits (which are discussed further in section 3) are reflections of a concept of democracy that reflects the Westphalian state system and is therefore difficult to apply to the context of European integration (Eriksen \& Fossum 2012). In a sense, given this grounding in a Westphalian understanding of democracy as inherently bound to the context of the nation state, the alleged democratic deficit is a genuine conundrum: if democracy can only be achieved within the nation state, then the EU would either have to become (much more like) a state, or it would need to significantly scale down the scope of its integration activities.

The upshot of debates on the democratic deficit is less that there is something wrong with the EU's institutional architecture, but instead that there is something wrong with democratic theory, as the latter does not allow us to "think outside the box" and imagine democratic procedures beyond the nation state (cf. Eriksen \& Fossum 2012). To begin with, the two dominant ideas regarding the sources of legitimacy that the European integration process has to draw on are both essentially state-based: the EU can remain at the level of an intergovernmental problem-solving organization along Moravcsik's lines; or it can develop into a European federation based on a community of cultural values. In the former scenario, its problem-solving capacity would serve as its exclusive (and sufficient) source of legitimacy (Eriksen \& Fossum 2004). Unless the organization can demonstrate that it can solve given problems better or more effectively than the nation state, it would have to be considered illegitimate. This would also imply that there is no need for democratic 
legitimation at the European level, as indirect legitimation via the member states would suffice in a model of democracy that could be described as "audit democracy" (Lord 2012; Eriksen \& Fossum 2012: 22f.).

The latter scenario reminds us that legitimacy is not necessarily democratic legitimacy. European integration can be said to suffer from a number of community deficits that can be viewed as the root cause of the democratic deficit. Kielmansegg observed already in 1996 that Europeans do not share a politically relevant collective identity because Europe "is no community of communication, barely a community of memory and only to a very limited extent a community of experience" (Kielmansegg 1996, quoted in Conrad 2009: 42). Etzioni similarly argues that the democratic deficit is perceived as such foremost because European integration has proceeded into policy areas in which communitarization would require a significantly stronger sense of "normativeaffective community", i.e. a sense of European community that arises from shared moral values (Etzioni 2007). In this sense, concerns about a lack of democracy can better be described as a byproduct of the perception that integration has gone too far.

Etzioni's notion of the community deficit further explains efforts made to overcome the community deficit by emphasizing cultural similarities between the EU member states - not so much because it would enhance the democratic legitimacy of the European integration process, but much more because it would provide for a sense of cultural community of values that could in turn serve as a source of legitimacy. This communitarian strategy is often portrayed as connected to the idea of federalism, arguably because it draws on the idea that federations are characterized by "unity in diversity", i.e. by a balance that needs to be struck between creating strong central institutions while maintaining as much of the autonomy (and indeed identity) of the constituent units as possible (see section 2). Nevertheless, even federations - in this communitarian understanding - require a sense of collective identity to start out with.

Yet this is not the kind of federalism we are talking about in the context of this article. Our argument is that the link between federalism and communitarian legitimacy is exaggerated. As a consequence, our interest is in the contribution that federal reorganization can make towards the specific goal of democratic legitimacy. Federalism can provide institutional means to generate democratic legitimacy, even (and specifically) in the absence of a thick sense of collective identity. Democratic theory has so far merely begun to theorize the conditions for democracy outside the context of the nation state. Habermas pointed out already in his essay on the "postnational constellation" that inasmuch as decisions are increasingly made in forums outside the nation state, there is a clear need for a reconstitution of democracy, preferably at the European level (Habermas 1998). Recently, Eriksen \& Fossum (2012) have emphasized that the debate on the future of democracy in the EU is quite problematic, as the first two models identified so far - audit democracy in what is essentially a problemsolving organization, or federal democracy in what is essentially a culturally integrated regional European state - fail to take us any further as regards the question on the link between the (nation) state and democracy: both are founded on the same state- 
centered premises. This idea is further underlined in James Bohman's criticism of transformationalist democratic theory in the tradition of Habermas and Held, which Bohman considers to be much less transformationalist than necessary: merely reconstituting democracy at the European level (through European demos construction) not only produces more of the same kind of democracy, but creates a problematic relationship between the newly created European demos and the already existing and democratically constituted member state demoi (in the plural) (Bohman 2007).

In this article, we are therefore exploring the contribution that federalism has to make in terms of democratic legitimacy in a European polity that would not be based on a reconstitution of Europe, but rather on a reconfiguration of democracy along the path staked out by Eriksen and Fossum (2012): federalism has a contribution to make precisely because the European Union would have to become a novel kind of rights-based, postnational polity. Against this backdrop, it is wrong to assume that the question of EU democracy requires a reconstitution of Europe to fit existing state-based models of democracy (i.e. models 1 or 2 discussed above). Instead, the future of democracy in the EU urges democratic theory to engage in a more fundamental reconfiguration of democracy, specifically to develop a democratic theory that disconnects the institutional form of democracy from the nation-state context within which it has emerged. If anything, European integration challenges the taken-for-granted understanding that democracy is only possible within the nation state. Federalism, at least as long as it is framed in terms of the EU conceived as a rights-based, postnational polity can develop a decentered understanding of democracy that is not founded on the notion of the popular sovereignty of a single unified demos, but rather on a non-hierarchical coexistence of a multitude of national (and indeed subnational) demoi and one overarching European demos. The Habermasian notion of constitutional patriotism is certainly relevant in this context inasmuch as it provides a basis for imaging the sort of "identity light" (Risse 2004) that would be necessary to sustain such a coexistence of already democratically constituted national demoi (Conrad 2009). As a mode of attachment, a European constitutional patriotism would be based on political identification with moral, political and legal principles as well as liberal democratic procedures which are entrenched in a common constitution (Mueller 2008: 545; Thomassen 2010: 144f.). Europe is far too diverse and fragmented for integration to be based on one common cultural community and the shared values that would constitute it (Thomassen 2010: 41). Social integration would be sufficient at the political level (ibid.: 145), clearly resonating very well with the kind of federalism proposed here, following the rights-based idea of a postnational polity. 


\section{European Integration and the Legacy of Federalism}

\subsection{Unity in Diversity: Conceptual Foundations of Federalism}

Both in debates about the future of European integration or on institutional reform in the EU, federalism is frequently mistaken to imply excessive centralization, i.e. more or less the exact opposite of the form of decentralized democracy that the concept actually suggests, both in terms of its etymological origin and in terms of its institutional reality (Stepan 2004b: 57-59; MacAskill 2001). This suggests that the concept itself bears more power to frame debates than its institutional implications, but it also motivates a closer look at the etymological origin of federalism. The latter is far more than a trivial language lesson, as it contributes both to a fundamental understanding of federalist theory and to an appreciation of the opportunities as well as challenges of a federal reorganization of Europe. The word 'federalism' derives from the Latin root foedus, meaning agreement, bargain or contract; but it also derives from fides, meaning faith or trust (Burgess 2000: 13; King 1982: 56). This contractual connotation is captured in Livingston's definition of federalism in terms of power sharing between central and regional units that are endowed with certain functions and powers that one cannot be deprived of by the other (Livingston 1952: 81; italics added). Similarly, Elazar described federalism as the combination of shared rule and of selfrule where two or more polities find it requisite and desirable to live within a constitutional framework that will allow them to hold on to their diversity whilst securing stability and peace through power sharing where necessary (Elazar 1991).

The etymological root of the concept implies both trust and contract the fundamental principle of "unity in diversity": federations create a contractual relationship that ties them together in common institutions, but that nonetheless allows them to retain as much of their individual autonomy as possible. It is therefore unsurprising that the focus of most federalist theories is on securing diversity, preserving a plurality of identities while at the same time making a commitment to power sharing in a stable political union (Hueglin 2003: 282).

\subsection{Identity, Federalism and Federation}

In this sense, we can already identify a certain conceptual problem when federalism is dismissed for lack of a preexisting sense of collective identity. More importantly, however, it is problematic to confine federalism to a communitarian strategy for legitimating European integration: a collective identity may emerge as a byproduct of the process of political integration, but it certainly cannot be the starting point of the integration process. This question requires us to take a closer look at the relationship between federalism and questions of collective identity.

In this context, it is highly relevant to point out that federalism is not merely a form of organizing power at different levels of government. In our analysis, what is more important is the fact that federalism tends to be a plausible alternative most of all in settings characterized by (deep) diversity, i.e. settings that cannot derive legitimacy from a strong sense of collective identity. This distinction is also captured in the distinction between federalism and federation, i.e. between federalism as a normative 
concept and federation as the institutional embodiment of these principles (King 1982: 76-79). :

Federalism has become an important part of the theoretical discourse on the organization and structure of the state as well as interstate relations (Burgess 2000: 23). Consequently, many nowadays see some form of federalism as the best institutional answer to the cosmopolitan, interchangeable reality of the modern world, and it is therefore unsurprising that it is particularly popular in . societies marked by deeprooted lingual, cultural and ethnic diversity (Watts 1998: 118; Stepan 1999: 19). The high-scorers on the index of linguistic and ethnic diversity - Canada, Belgium, Spain, Switzerland, India and the U.S. - are all federal political systems (Stepan 1999: 20). The Belgian case can also be used as a case in point underlining the relevance of federalism in the absence of a strong sense of collective identity. But it should also be emphasized that the strength (or lack thereof) of a "federal" identity is less important in the choice for federalism than the strength of the identities of the constituent units. Some federations - such as the US or Germany - have quite strong senses of national identity, but it is the salience of "national" identities at the substate level that explain the relevance of federal organization.

\subsection{The Legacy of Federalism}

Against this conceptual backdrop, the perception of the concept of federalism as a taboo in debates on European integration is bewildering, not only because the EU already today has quite a few federal features. Most of all, it is puzzling considering the potential contribution that federalism can make, not just in broader terms of democracy and legitimacy, but specifically in relation to postnational democracy founded on constitutional patriotism. In this context, federalism hardly appears as a very threatening concept, at least as long as its meaning, roots and practical implications are correctly understood and appraised.

Without these considerations, it would be difficult to fathom why federalism has played as profound a role as it has in shaping the ideas of the founding fathers of the integration process. The legacy of federalism in the European context begins long before the integration process itself. Already in the interwar period, Richard Coudenhove-Kalergi's "Pan-Europa" was published as a plea for a unification of Europe (Gehler 2006). Like many others at the time, Coudenhouve-Kalergi regarded the creation of a Pan-European Union as the best way to protect Europe from war, rising communism and fascism. For Coudenhove-Kalergi, this Pan-European Union would also serve as a necessary economic counterweight against the emerging world power, the United States (ibid.).

Federalism was similarly prominent among resistance movements during World War II (Bache et al. 2011: 6). The European Union of Federalists (EUF) emerged out of these movements in 1946, led by Altiero Spinelli (ibid.). In the Ventotene Manifesto, Spinelli and Rossi were motivated by the vision of a new kind of Europe composed of individual units that relinquished part of their autonomy to collective democratic institutions (Nelsen \& Stubb 2003: 91). Spinelli and Rossi viewed the existence of 
sovereign nation states as the source of all violent conflict in Europe. Nonetheless, the point to be made about federalism is valid: a federal arrangement makes sense precisely because of the absence of a strong sense of European identity.

Also Monnet and Schuman, the two founding fathers whose names are intimately linked with neofunctionalist theorizing about the integration process, had a clear federal goal in mind. Their approach was however not "revolutionary federalism" as in the Ventotene Manifesto. Nonetheless, their incremental approach to integration had the intention of developing an integrative momentum that would lead to a gradual federalization of Europe. The Monnet method of incremental integration is clearly motivated by an awareness of the strength of national identities in Europe. Against this backdrop, it is unsurprising that Monnet spoke of a "chain reaction, a ferment where one change induces another (Nelsen \& Stubb 2003: 19).

In his famous speech at Humboldt University in Berlin in May 2000, Joschka Fischer - at the time Germany's foreign minister in the "red-green" coalition government of Chancellor Gerhard Schröder - is similarly aware of the strength of national identities and therefore proposes a federation of nation states as the "completion of European integration" (Fischer 2000). Some observers criticized this ambition as an attempt at "squaring the ciricle", as any federalization would necessarily have to come at the expense of the nation state (cf. Conrad 2009: 143). Fischer's vision entailed a decentralized federal model, in tune with classical federalism, a union with wider powers, greater democratic accountability as well as a more straightforward system of decision making.

In the wake of the ensuing "finality debate", Guy Verhofstadt - at that time Prime Minister of Belgium - supported Fischer's ideas, calling for a deeply integrated, federal EU with an elected president as well as bicameral legislature on par with the parliamentary systems of fully-fledged nation-states. His focus was on deeper and quicker integration in many competences as well as speedier enlargement (Collignon 2006). Notable in this context is also the publication of his book "The United States of Europe" in the aftermath of the French and Dutch referenda on the Constitutional Treaty in 2005. Here, Verhofstadt advances the vision of a federal Europe of all existing EU member states. Aware as he was of the reluctance of at least certain member states to go further into this direction, he also advocated the idea of a political "core", a number of "pioneers" that would be able to integrate more fully without being held back by the skepticism of the member states which didn't (Verhofstadt 2006).

In sum, we can therefore look at proposals for a federalization of Europe in part as a means to achieve an end, namely to provide solutions to existing and emerging political problems. But more importantly, federal solutions - whether in the form of the Ventotene Manifesto, Schuman \& Monnet's ferment of change or Fischer's federation of nation states - tend to take into account the lack of a strong sense of European identity as well as the resilience of national identities. This is further reflected in the most current responses to the Eurozone debt crisis. In the latter context, a strengthening of the supranational institutions is urged, yet without any 
reference to federalism so as not to suggest a further undermining of the nation state and national identities.

\section{The Costs and Benefits of Federal Reorganization}

If federalism can point us in the direction of institutional solutions to the EU's current problems despite the absence of a stronger sense of European identity, we need to ask what the costs and benefits of a potential federal reorganization of Europe are from the perspectives of democracy, legitimacy and sovereignty. From a supranational perspective, the democratic benefits of federal reorganization are fairly self-evident, at least as compared to the status quo of the EU as a polity sui generis, which is after all part of the problem of the perception of the democratic deficit (see section 1). Democracy can be defined as rule of the people, deriving as it does from the ancient Greek dèmos, which means people, and kratos, which means rule. This simple etymological point raises relevant questions for democratic theory, specifically whether democracy beyond the nation state should be the rule of a newly created people/demos beyond the nation state, or whether the concept of democracy should be dissociated from the notion of popular sovereignty and become rule of peoples in the plural (Bohman 2007). From our perspective, federalism can be both, as our conceptual introduction made clear: rights-based, postnational federalism involves both European demos construction and the institutionalization of non-domination.

Federal structures offer democratic communities a way of staying intact whilst preserving a measure of self-rule (Smith 2004: 26). Chryssochoou identified a federal model of democracy and described it as resting on the formation of a unity of people (i.e. a unified demos) rather than merely a union of states. This model seeks to reconcile the conditions of greater political union with the claims of the constituent states. In doing so it aspires to set up a co-operative democratic ethos in interaction between the center and its subunits (Bache et al. 2011: 74). The normative implications of federalism require federations to build their legitimate foundation on a contract of trust between all subunits (King 1982: 88). All citizens of the member states are simultaneously rendered directly subject to the authority of the center through equal citizenship (ibid.: 89). These citizens are incorporated into the national decisionmaking structure - the citizens of every region enjoy a degree of direct control over the central government, and the government has some direct responsibility towards the people as a whole (ibid.). Consequently, also equality is a core principle of federalism, manifesting itself in the fact that each constituent unit is assigned the same set of government responsibilities under the federal constitution. The constitution then assigns all citizens the same rights and responsibilities. Federalism can encourage democratic diversity by creating a system of harmonized but autonomous spheres of influence, based on a division of authority among state and federal agents, component legislatures could hold their executives accountable to their particular publics whilst a European legislature could operate as a possible barrier against the perils of central executive dominance (Smith 2004: 28-31). 


\subsection{Europe's Democratic Deficit}

Considering the contested nature of the EU as a polity (or as an 'unidentified political object'), democratic theorists have been perplexed with regard to examining the democratic qualities of the EU and comparing them to the ideals of state-centered democratic theory. Among the most commonly enumerated features of the EU democratic deficit are deficiencies in representativeness and accountability and the lack of a European demos (Warleigh 2003; Bache et al. 2011: 69; Abromeit 1998: 4). Elsewhere, these deficiencies have been described as an institutional/parliamentary deficit, a constitutional deficit and a European demos deficit (Chryssochoou 2000: 4). The institutional/parliamentary deficit is commonly brought up in context with the still relatively weak European Parliament. The European Parliament isn't a true legislative body in the conventional sense (Majone 1998: 6-7), as it has to share its legislative power with both the Commission and the Council of Ministers. Neither is it a body for enforcing "political responsibility," i.e. to hold government accountable to its electorate (Abromeit 1998: 4). The core of every representative democracy is its parliament; parliament is the ultimate source of legitimacy in representative democracies. Consequently, many argue the importance of creating a true parliamentary basis for EU democracy (ibid.). The EU today is often said to be legitimated (only) indirectly via the nation states (Moravcsik 2008; cf. Eriksen \& Fossum 2004, 2007). At the same time, it can be pointed out that national electorates are rarely, if ever, given the opportunity to express their opinions on European issues in national elections (Abromeit 1998: 5). Of course, the role of the EP has been gradually strengthened since the first direct elections in 1979, suggesting a gradual correction of the EU parliamentary deficit. However, voter turnout in EP elections remains low, and election campaigns are dominated by domestic rather than European issues (Jensen 2009: 2). The Parliament itself seems not to have managed to make itself relevant to most Europeans (Gallagher et al. 2006: 128).

In this context, it is worth emphasizing the lack of strong accountability mechanisms. EU citizens are at best in a very limited way able to hold EU decision makers to account. In addition to the fact that the EU political system and decision-making processes have by no means become simpler over the years, the European Commission and the Council of Ministers are at best indirectly legitimated at the national level, making it impossible for EU citizens to "throw the rascals out" if voters do not like specific decisions or policies, or the general direction of EU decision making as such. As a matter of fact, it can even be difficult to identify the responsible "rascals" in the first place (Gallagher et al. 2006: 128; Jensen 2009:4; Chryssochoou 2000: 12).

In addition to these deficits of accountability and representativeness, the division of competences between union and national institutions is hazy (Chryssochoou 2000: 10-12). The idea of executive dominance in the EU suggests tangible tensions already at the national level, specifically between national governments and national parliaments, as governments evidently seek to bypass their parliaments in the context of EU decision making. Governments are represented in the Council of Ministers, while national parliaments - despite certain changes in the Lisbon Treaty - are for the 
most part excluded from the decision-making process, except in the case of ratification and legitimation (ibid.). EU activities remain under a great deal of influence from national governmental elites (ibid.). There is thus a need for transformation "from a system of democratic governments into a democratic system of government (ibid., 14)."

The constitutional deficit lies in the fact that Europe doesn't possess a common constitution. While the failed constitutional treaty boasted of constitutional symbolism, a clearly codified European constitution outlining respective areas of union and member state competence is still missing. Globalization is continually undermining the nation state's problem-solving capacity and by extension its legitimacy, with profound consequences for state sovereignty (Habermas 1998; Thomassen 2010: 139). The fact that decisions are increasingly made in forums beyond the nation state therefore necessitates a transformation and reconstitution of democracy at the same level. The most suitable solution available for Europe in this regard would arguably be the reconstitution of democracy at the level of a federal Europe through the making of a common European constitution (Habermas 1998), in line with the idea of the EU as a postnational polity (Eriksen \& Fossum 2004, 2007). This approach, as indicated above, would only be democratically beneficial if it was clearly distinguished from the idea of a federal European polity based on a culturally defined community of values (cf. Eriksen \& Fossum 2004).

This leaves the thorny question of the demos deficit. In this context, we should remind ourselves that democracy is of course not only a question of who governs, but also of who is governed (Chryssochoou 2000: 1). In representative democracies, democratic legitimacy rests to a significant extent on processes of public opinion and will formation. In the language of Habermasian deliberative democracy, the communicative power of the public sphere has to be channeled into the institutions of the political system, and the latter constantly has to try to win the approval of the public sphere (Habermas 1992). The existence of a European demos has been disputed by many. The same applies to the level of citizen identification with the European project despite its success in furthering integration. European citizens still do not view themselves as a collective of members of a single political body (Lacroix 2002: 944). However, the demos deficit is too often addressed from the static perspective of constitutional law, without discussing the notion that identification with the state - and other citizens of the state - emerges out of democratic practice itself (Conrad 2009: chap. 1).

\subsection{Federal Reorganization: Democracy, Legitimacy, Sovereignty}

What impact would a federal reorganization of the Union have in terms of democracy, legitimacy and sovereignty? From a federalist perspective, there is a clear link between the institutional/parliamentary, constitutional and demos deficits, with European constitution making coming up as a possible remedy to these three deficits. Federal reorganization would necessarily entail substantial institutional reform. From the point of view of democracy, one main task of this institutional reform project would 
have to be to strengthen existing and to introduce new mechanisms of democratic accountability. This lack of democratic accountability is a direct result of the continued legacy of intergovernmentalism in the EU. All three major legislative institutions come to mind in this regard. Only the European Parliament is is directly accountable to the European citizens already at this point. However, its legislative competences would need to be extended to match that status. Even if the EP did not become the sole initiator of the legislative process, the right of legislative initiative would nonetheless need to be extended to the EP in order for the accountability to the European citizens to actually mean something.

But if the aim is to achieve stronger accountability of the European institutions, then the respective roles of the European Commission and the Council of Ministers also require substantial rethinking from a federalist perspective. Regarding the Commission, this applies mostly to the role that the EP could play in determining the Commission President and the composition of the College.. A European Commission turned into an accountable European quasi-government is certainly high on the federalist wishlist. Of course, the evident benefit of democratic accountability would have to be weighed against the cost of decreased governmental control over the European Commission. Again, the lack of accountability of the Commission is testimony to the intergovernmental legacy in European integration. Increasing its accountability is therefore democratically plausible, but is highly problematic if member states are committed to an intergovernmental integration process based on the EU institutions' problem-solving capacity and "audit democracy" (Lord 2012; Eriksen \& Fossum 2012).

The current system of choosing Commissioners is a case in point. The process whereby national governments nominate their respective Commissioners can rightfully be criticized for being untransparent. The same applies to the selection of the Commission President by the European Council. The Lisbon Treaty has gone some way in remedying this by making the choice of Commission President - formally still in the hands of the European Council - a politicized process in which the European Council's choice has to reflect the outcome of the previous EP elections (Art. 17 TEU; Bache et al. 2011: 256f.). But a democratically more plausible approach would be for the European Parliament not merely to formally elect a candidate pre-determined by the European Council, but rather to elect the Commission President from a number of candidates representing (and supported by) the EP's different party groups. This would greatly enhance the accountability of the Commission President and by extension of the Commission as a whole. However, it would also make the process more supranational and, as a consequence, undermine the role of the European Council in this regard. In addition, considering the increased democratic legitimacy of the Commission in this scenario, it might trigger a gradual process of extending the "governmental" functions of the Commission, similar to the process of extending the rights of the European Parliament in the years after the first direct elections in 1979. This would not be a problem from the federalist perspective, but it would represent a significant step away from the tradition of intergovernmentalism, 
which by necessity comes with lower democratic expectations than a federalist vision of the integration process.

A development in this direction would also have implications for the role of the Council of Ministers. Joschka Fischer proposed the role of a second chamber of parliament for the Council of Ministers, either in the form of a Senate modeled after US federalism (with senators directly elected at the level of the member states), or "a chamber of states" along the lines of German federalism. The remarkable aspect is obviously that both these federal solutions - albeit to different degrees - would strengthen the role of the smaller and smallest of the union's member states, from a system of digressive proportionality (see section 4 below) to a system that either does not take member state size into account at all (in the Senate scenario), or only to a marginal extent (as in the "Bundesrat" scenario). It is well known that this overrepresentation of smaller units is a standard feature of federal systems, facilitating the accommodation of difference and sub-national demands (Bermeo 2004: 468). Disproportionality at the parliamentary level is a way of providing checks and balances for minorities as well as protection for smaller units in a larger entity (ibid., 470). If a polity is large, multinational and linguistically diverse, like the EU today, its chances of being democratic thus improve significantly with the adoption of a federal political system (ibid., 468). Again, the absence of a strong European identity is an argument for, not against federalism. Consequently, even if no European demos exists at this moment, at least not at the desirable level, it might be brought into being as a political identity by the experience of a common constitution and government, as was the case in a number of countries, such as Switzerland (Gallagher et al. 2006: 148).

The upshot of these reflections is clearly that institutional reform along federal lines produces quite different results in terms of democracy, legitimacy and sovereignty. If accountability is the problem, then clearly, a lot is to be gained from the reforms sketched above. Increased accountability should also enhance the democratic legitimacy of the European institutions and their legislative output. However, this assessment is already based on an understanding of democracy as rooted in the tradition of popular sovereignty. Some will continue to argue that democracy and popular sovereignty can only be institutionalized at the level of the nation state. If this claim is valid, then the values of accountability and democratic legitimacy and sovereignty would need to be played off against one another. Our argument is that such state-based accounts of democracy and popular sovereignty no longer capture the complex empirical reality of European integration. Increased mechanisms of accountability at the supranational level generate increased democratic legitimacy and contribute to a reconstitution of sovereignty at the European level.

\section{What's in it for small states?}

The prospect of a federal reorganization of the European Union is of particular salience from the perspective of the union's smaller states, based on the fundamental assertion that federal systems usually display a significant overrepresentation of the smaller and smallest of their respective constituent units. This overrepresentation in 
fact exceeds the principle of "digressive proportionality" that is already practiced in the EU, both in the European Parliament and in the Council of Ministers (Bache et al. 2011). The following section elaborates on these points not only in order to demonstrate how federal structures - and indeed international organizations - are beneficial to smaller states, even to the extent that some observers find the principle to be "in open contrast to political equality" (Neyer 2012: 526) ${ }^{1}$. The more relevant point arises from the union's consensus culture despite the fact that qualified majority voting (QMV) in the Council of Ministers is by now part of the ordinary legislative procedure and thus the norm in EU legislative decision making. Most important to note in the context is however Thorhallsson's criticism of traditional understandings of state size in international politics in general as well as in the EU in particular (Thorhallsson 2006; Thorhallson \& Wivel 2006).

The traditional dilemma of small states lies in the contradiction between the desire to retain autonomy and the desire to exert influence (Goetchel 2002: 17). Federalism opens a path to reconciling these contradictory claims. As we have seen, federal arrangements allow small states to retain their identity while securing stability by sharing authority with a larger entity in areas where it is practical. In a federation, small states can preserve their national autonomy while being able to count on infrastructural and political resources and opportunities for influence that they would otherwise be short of (Goetchel 2002: 18). The threat of extinction is considerably lessened by tying the existence of the state to a common federal constitution, which no single level of government is able to change on its own. In the face of globalization and continually growing international interdependence, federal arrangements thus offer small states cooperative ways to maximize their influence in the international arena. The practical reality of federations is that smaller units usually either have equal representation in the respective chambers of states or are at least significantly overrepresented (Stepan 2004b: 55). ${ }^{2}$

Due to the principle of digressive proportionality (art. 14, Lisbon Treaty), the smallest states in the EP are already heavily overrepresented in relation to their population (Bache et al. 2011: 293). ${ }^{3}$ Larger EU member states have criticized these disparities and are said to continually try to augment their own powers at the expense of the smaller states (Pórhallsson 2007: 643), not least because "Eastern" enlargement has profoundly increased the number of smaller states in the EU, creating a stronger counterbalance versus the larger ones (Antola 2002: 70). Yet while this overrepresentation of smaller states might appear to constitute a violation of the principle of equality (Neyer 2012, see above), the principle of digressive proportionality has also been argued to be the politically most sustainable option available at this time (Dinan 2010a: 102f.; cf. Antola 2002: 71). In a federal arrangement, this principle would nonetheless be able to claim higher democratic legitimacy than at present. (Dinan 2010a:, 241).

The strongly institutionalized consensus culture in the Council of Ministers further indicates that small states in the European Union are by no means powerless in the face of larger ones, although - as noted above - qualified majority voting (QMV) is by now the norm in legislative decision making in the Council. Concerns voiced in the 
run-up to the Lisbon Treaty regarding the risk that this more or less complete abolition of the "national veto" would undermine the role of small states in the institutions of the EU have turned out to be no more than a theoretical possibility. State size itself is hardly a relevant cleavage in voting patterns in the Council of Ministers. More importantly, however, there is still a strong tradition of consensusbased politics in the EU.

The role that small states play in the EU institutions further needs to be differentiated by reference to Thorhallsson's criticism of traditional definitions of state size (Thorhallsson 2006). While there is more to the image of a state's influence in the EU than size, the notion of size may nonetheless shape the behavior and influence of nation states as well as their identity and action capacity (Thorhallsson 2006). The behavior and capacity of states in the international arena is often deduced from traditional indicators of state size, e.g. territory, economic size and military capacity (ibid., 27). From a social constructivist perspective, one might however object that these indicators do not explain the considerable success of small states in influencing the agenda in the EU, as for instance the literature on the Council Presidency suggests (Elgström 2002; Bengtsson 2004; more recently Kaniok 2012). Objective factors such as domestic politics and economics, administrative capability and scope, ambition as well as strategic stances can influence the perception of state size today (Thorhallsson 2006: 7-10).

To overcome this gap, Thorhallsson introduced "perceptual size" and "preference size" as new indicators of state size, which are particularly relevant in strongly institutionalized normative environments such as the European Union. Perceptual size refers to the perception held by the state itself and by other actors about its potential for influence (Thorhallsson 2006: 24), whereas preference size refers to a given state's ambitions, priorities and ideas about the international system, i.e. its level of ambition as regards international activities (ibid.: 26). Scandinavian countries count as small states on the basis of traditional indicators, yet have a self-perception as well as a proven track record of "active foreign policy", as in the Swedish case (Elgström 1982). By the same token, Luxembourg is by all means a small state in terms of traditional indicators, yet few would dispute that the country is a key actor in European integration. Institutional opportunities such as e.g. the Council Presidency therefore provide significant tools for small states to shape EU decision making (Broman 2008), which in turn has a profound impact on their self-perception as international actors.

To sum up these arguments, state size as defined by traditional indicators is at best only part of the picture in the EU. This is due in part to the principle of digressive proportionality and in part to the still strongly institutionalized consensus culture in EU decision making. These aspects can be observed already today and are well documented in the literature, even though the EU as a polity sui generis can at best be defined as a political system with certain federal features. A fuller federal reorganization would therefore only reinforce these elements in the institutional architecture of the $\mathrm{EU}$, all the more so if the EU were to develop into a bicameral system of governance in which the Council of Ministers would play the role of a chamber of states. 


\section{Conclusion: Still the F-Word in European Integration?}

This article was written out of a concern for the future of democracy in the European Union. While European integration is considered to be increasingly controversial not least in the wake of the Eurozone debt crisis, the process is certainly highly likely to continue well into the future, although some observers hold that "the jury is still out" regarding this question (Fossum \& Menéndez 2012: 57). Assuming that we can treat European integration as a fact, the question that begs an answer is not only what kind of democracy is possible and indeed necessary in the polity sui generis as which we have come to understand the EU. In addition, the question also arises what kind of democratic theory is necessary to answer questions about the democratic character of decision making in arenas outside the nation state. As we have seen, European integration fundamentally challenges the categories of state-based democratic theory, in particular the notion of popular sovereignty when applied to supranational and, potentially, postnational settings. In this article, we have in many ways played devil's advocate, making the case for a reconsideration of federalist theory as a blueprint for institutional reform in the ongoing process of democratization in the EU. Our most fundamental point is that federalism is by no means automatically to be associated with the communitarian understanding of a European federation integrated and sustained by a cultural community of values. Neither is it to be associated automatically with the kind of highly centralized (super-)state structure that many Euroskeptics appear to have in mind when addressing what has increasingly come to be perceived as the Fword in European integration. Instead, our main contention is that classical federalism, with its emphasis on decentralized democracy and unity in diversity, is perfectly compatible with the cosmopolitan understanding of democracy in a rights-based, postnational European Union, founded on principles of constitutional patriotism. It is therefore unsurprising that Habermas, whose writings have after all inspired the whole literature on the EU as a postnational union, emphasizes the need for EU constitution making, despite the reservation that this kind of Eurofederalism may be little more than a mere reproduction of the same kind of democracy at a higher level.

Our treatment of federalism staked out a fairly straight-forward path to democratic institutional reform in the EU. With an emphasis on democratic legitimacy and accountability, we demonstrated that a strengthening of the supranational institutions could - and indeed would have to - go hand in hand with creating a form of direct accountability mechanisms that does not exist in the EU as of today. We further argued that this lack of accountability - as part and parcel of the democratic deficit is no coincidence, stemming as it does from the intergovernmental legacy of the integration process. Although it is usually intergovernmentalist skeptics of further integration who bemoan the democratic deficit, they are the same who also resist any moves in the direction of further supranationlization. We further emphasized the particular relevance of federalism for small states. Due to the already existing federal features of the EU's institutional architecture, we can observe a fairly obvious overrepresentation of small states in the EU's major institutions. Were the EU to go even further down the federal path, these elements would be likely to become even 
more pronounced. But even as the EU is today, the principle of digressive proportionality in the European Parliament and the consensus culture in the Council of Ministers are testimony to the role and power potential of small states.

One thorny issue remains nonetheless. The possible routes for institutional reform we have presented and assessed here will matter little in terms of the ongoing democratization of the EU if there continues to be fundamental disagreement about the basic meaning of democratic rule. For those who subscribe to the notion that democracy, as rule of the people, is bound to the context of democratically constituted national communities, any move in the supranational direction will be normatively inappropriate, as will be a profound reconstitution of democracy at the European level. From this perspective, the very notion of European demos construction is a fundamental blow to the notion of national sovereignty. But then again, even from this perspective, it is virtually impossible to get around the fundamental observation that more and more decisions in the globalized world are taken in forums beyond the nation state. It is hardly news that these processes not only undermine the sovereignty of the nation state, but also its legitimacy. Against this backdrop, the need for a reconstitution of democracy presents itself with profound urgency. Again, European integration - whether as a response to economic globalization or otherwise - is a fact; whether, to what extent and in what ways the process should be created democratically is up to the Europeans themselves.

\section{Notes}

1 Jürgen Neyer acknowledges that this is a standard feature of federal systems, but maintains that the EU for one is not a federal polity, and that by comparison to federal polities, the principle of digressive proportionality applies to both legislative chambers.

2 In Germany's Bundesrat, even the largest state (North Rhine - Westphalia) has only six votes, while the smallest state (Bremen) has three - although the former state has around 27 times the number of inhabitants than the former. In the U.S. Senate, the rule is one state, two representatives, and the difference in population between the smallest and the largest state there is even greater than in Germany (Stepan 2004b: 55).

3 One Maltese MEP represents only about 66.000 inhabitants, while one German MEP represents as many as about 860.000 residents (Dinan 2010a: 239).

\section{References}

Abromeit, H., 1998. Democracy in Europe: Legitimising Politics in a Non-State Polity. New York, Oxford: Berghan Books.

Antola, E. 2002. 'The Future of Small States in the EU', in M. Farrel, S. Fella \& M. Newman (eds.), European integration in the 21 st century: Unity in diversity? London: SAGE Publications.

Bache, I., George, S. \& Bulmer, S. 2011. Politics in the European Union (3rd ed.). New York: Oxford University Press.

Bengtsson, R., Elgström, O. \& Tallberg, J. 2004. 'Silencer or Amplifier? The European Union Presidency and the Nordic Countries', Scandinavian Political Studies 27, 311-334.

Benson, D. \& Jordan, A. 2008. "Understanding task allocation in the European Union: Exploring the value of federal theory", Journal of European Public Policy 15 (2008): 78-97.

Benson, D. \& Jordan, A. 2011. "Exploring the Tool-kit of European Integration Theory: What role for Cooperative Federalism?”, Journal of European Integration 33, 1-17. 
Bermeo, N. 2004. 'Conclusion: The Merits of Federalism', in Amoretti, U. M. \& Bermeo, N. (eds.). Federalism and Territorial Cleavages. Baltimore: The Johns Hopkins University Press.

Bohman, J. 2007. "Democratizing the Transnational Polity. The European Union and the Presuppositions of Democracy", RECON Online Working Papers 2007/02.

Broman, M. 2008. Taking advantage of institutional possibilities and network opportunities: analyzing Swedish strategic action in EU negotiations. Lund: Department of Political Science.

Burgess, M. 2000. Federalism and European Union: the building of Europe 1950-2000. London: Routledge.

Collignon, S. 2006. 'Introduction', in Verhofstadt, G., The United States of Europe. London: Federal Trust for Education and Research.

Conrad, M. 2009. Between Communication and Community: EU Constitution-Making, a European Public Sphere and the (Un-) Likelihood of Transnational Debate. Lund Political Studies 158. Lund: Department of Political Science.

Conrad, M. 2010. "The Missing Link in EU Democracy? Why a Transnational Public Sphere Matters", Stjórnmál og stjórnsísla 6(2): 207-228

Conrad, M. 2011. "The European Citizen's Initiative. Transnational Democracy in the EU at last?" Stjórnmál og Stjórnsýsla 1 (2011): 5-22.

Chryssochoou, D. N. 2000. Democracy in the European Union. London and New York: I. B. Tauris Publishers.

Dinan, D. 2010a. Ever Closer Union: An Introduction to European Integration, $4^{\text {th }}$ ed. London: Palgrave Macmillan.

Dinan, D. 2010b. 'Institutions and Governance: A New Treaty, a Newly Elected Parliament and a New Commission', Journal of Common Market Studies 48 (Annual Review): 95-118.

Elazar, D. J. 1991. Two Peoples... one Land: Federal Solutions for Isreael, The Palestinians and Jordan. Lanham, MD: University Press of America.

Elgström, O. 1982. Aktiv utrikespolitik: en jämförelse mellan svensk och dansk parlamentarisk utrikesdebatt 1962-1978. Lund: Studentlitteratur.

Elgström, O. 2002. 'Evaluating the Swedish Presidency', Cooperation and Conflict 37, 183-189.

Encyclopedia Britannica Online. "Democracy." http://www.britannica.com/EBchecked/topic/157129/democracy (accessed, 30. March 2012).

Eriksen, E. O. \& Fossum, J. E. 2004. 'Europe in Search of Legitimacy. Strategies of Legitimation Assessed', International Political Science Review 25, 435-459.

Eriksen, E. O. \& Fossum, J. E. 2007. 'Europe in Transformation. How to Reconstitute Democracy?', RECON Online Working Papers 2007/01.

Eriksen, E. O. \& Fossum, J. E. 2012. 'Europe's challenge: reconstituting Europe or reconfiguring democracy?', in Eriksen, E. O. \& Fossum, J. E. (eds.), Rethinking Democracy and the European Union. London and New York: Routledge.

Etzioni, A. 2007. "The Community Deficit”, Journal of Common Market Studies 45, 23-42.

Fischer, J. 2000. "Vom Staatenverbund zur Föderation - Gedanken über die Finalität der europäischen Integration", Forum Constitutionis Europae 12/00 (Spezial 2), Walter-Hallstein-Institut für Europäisches Verfassungsrecht.

Gallagher, M., Laver, M., \& Mair, P. Representative Government in Modern Europe: Institutions, Parties and Governments, $4^{\text {th }}$ ed. New York: McGraw Hill.

Gehler, M. 2006. 'From Paneurope to the Single Currency: Recent Studies on the History of European Integration', Contemporary European History 15 (2), 273-289.

Glencross, A. 2009. 'Altiero Spinelli and the Idea of the US Constitution as a Model for Europe: The Promises and Pitfalls of an Analogy', Journal of Common Market Studies 47(2): 287-307.

Goetchel, L. 2002. 'The foreign and security policy interests of small states in today's Europe', in Goetchel, L. (ed.). Small States inside and outside the European Union: Interests and Politics. Boston: Kluwer Academic Publishers.

Habermas, J. 1992. Faktizität und Geltung. Frankfurt a. M.: Suhrkamp. 
Habermas, J. 1998. ,Die postnationale Konstellation und die Zukunft der Demokratie', in Habermas, J. Die postnationale Konstellation. Frankfurt am Main: Suhrkamp.

Hueglin, T. 2003. "Federalism at the Crossroads: Old Meanings, New Significance", Canadian Journal of Political Science 36 (2003): 275-294.

Jensen, Thomas. 2009. "The Democratic Deficit of the European Union," Living Reviews in Democracy 1: $1-8$.

Kaniok, P. 2012. "The influence of the EU council presidency on public opinion", Romanian Journal of European Affairs 12(3): 19-32.

Kielmansegg, P. G. 1996. ,Integration und Demokratie', in Jachtenfuchs, M. \& Kohler-Koch, B. (eds.), Europäische Integration. Opladen: Leske + Budrich.

King, P. 1982. Federalism and Federation. London: Croom Helm.

Lacroix, J. 2002. 'For a European Constitutional Patriotism', Political Studies 50, 944-958.

Livingston, W. S. 1952. “A Note on the Nature of Federalism”, Political Science Quarterly 67 (1952): 81-95.

Lord, C. 2012. 'A Democratic Audit Framework', in Eriksen, E. O. \& Fossum, J. E. (eds.), Retbinking Democracy and the European Union. London and New York: Routledge.

MacAskill, E. 2001. 'Fischer in the Eurosceptics' Den', The Guardian, 25 January 2001.

Majone, G. 1998. 'Europe's "Democratic Deficit": The Question of Standards', European Law Journal 4 (1998): 5-28.

Moravscik, A. 2001. "Federalism in the European Union: Rhetoric and Reality", in Nicolaidis, K. \& Howse, R. (eds.) The Federal Vision: Legitimacy and Levels of Governance in the US and the EU. Oxford: Oxford University Press.

Moravscik, A. 2008. 'The Myth of Europe's Democratic Deficit', Intereconomics: Journal of European Public Policy (2008): 331-340.

Müller, J. W. 2007. Constitutional Patriotism. Princeton: Princeton University Press.

Mueller, J. W. 2008. 'A European Constitutional Patriotism? The Case Restated', European Law Journal $14,542-557$.

Nelsen, B. F. \& Stubb, A. (eds.) 2003. The European Union: Readings on the Theory and Practice of European Integration, 3rd ed. Boulder: Lynne Rienner Publishers.

Neyer, J. 2012. 'Who's afraid of justice? A rejoinder to Danny Nicol', Journal of Common Market Studies 50(3): 523-529.

Petersen, F. A. 1998. 'The International Situation and Danish Foreign Policy 1997', in B. Heurlin \& H. Mouritzen (eds.), Danish Foreign Policy Yearbook 1998. Copenhagen: Danish Institute of International Affairs).

Risse, T., 2004. ,Auf dem Weg zu einer europäischen Kommunikationsgemeinschaft: theoretische Überlegungen und empirische Evidenz', in Franzius, C. \& Preuß, U. K. (eds.). Europäische Öffentlichkeit. Baden-Baden: Nomos.

Smith, J. 2004. Federalism. Canada: The Canadian Democratic Audit, 2004.

Stepan, A. (1999). "Federalism and Democracy: Beyond the U.S. Model", Journal of Democracy 10, 19-34.

Stepan, Alfred. 2004a. "Federalism and Democracy", in Amoretti, U. M. \& Bermeo, N. (eds.). Federalism and Territorial Cleavages. Baltimore: The John Hopkins University Press.

Stepan, A. 2004b. "Towards a new comparative Politics of Federalism, Multinationalism, and Democracy: Beyond Rikerian Federalism", in Gibson, E. L. (ed.). Federalism and Democracy in Latin America. Baltimore: The Johns Hopkins University Press.

The New York Times. 2011. 'European Bankers Urge Leaders to Move Quickly on Debt Crisis', 5 September 2011.

Thomassen, Lasse. 2010. Habermas: A Guide for the Perplexed. London: Continuum.

Thorhallsson, B. 2006. 'The Size of States in the European Union: Theoretical and Conceptual Perspectives', European Integration 28(1): 7-31.

Thorhallsson, B. \& Wivel, A. 2006. "Small States in the European Union: What Do We Know and What Would We Like to Know?”, Cambridge Review of International Affairs 19 (4): 651-668.

Verhofstadt, G. 2006. The United States of Europe. London: Federal Trust for Education and Research. 
Warleigh, A., 2003. Democracy in the European Union. London: SAGE Publications.

Watts, R. L. 1998. "Federalism, Federal Political Systems, and Federations." Annual Review of Political Science 1, 117-137.

Dórhallsson, B. 2007. 'Davíð gegn Golíat: Hefur dregið úr möguleikum smáríkja til áhrifa innan ESB?’, in Jóhannesson, G. P. (ed.). Rannsóknir i Félagsvísindum VIII., 635-646. Reykjavík: Félagsvísindastofnun Háskóla Íslands. 